Article

\title{
Do Development and Diet Determine the Degree of Cannibalism in Insects? To Eat or Not to Eat Conspecifics
}

\author{
Francisco J. Fernandez ${ }^{1}$, Manuel Gamez ${ }^{1} \mathbb{D}$, Jozsef Garay ${ }^{2}$ and Tomas Cabello ${ }^{1, * \mathbb{C}}$ \\ 1 Center for Research in Mediterranean Intensive Agrosystems and Agrifood Bioechnology (CIAMBITAL), \\ Agrifood Campus of International Excellence (CEIA3), University of Almeria, Ctra. Sacramento, s/n, \\ 04120 La Cañada, Spain; javierfermal@gmail.com (F.J.F.); mgamez@ual.es (M.G.) \\ 2 Ecology and Theoretical Biology, Eötvös Loránd University, Pázmány Péter sétány1/c, 1117 Budapest, \\ Hungary; garayj@caesar.elte.hu \\ * Correspondence: tcabello@ual.es
}

Received: 29 February 2020; Accepted: 8 April 2020; Published: 14 April 2020

\begin{abstract}
Cannibalism in insects plays an important role in ecological relationships. Nonetheless, it has not been studied as extensively as in other arthropods groups (e.g., Arachnida). From a theoretical point of view, cannibalism has an impact on the development of more realistic stage-structure mathematical models. Additionally, it has a practical application for biological pest control, both in mass-rearing and out in the field through inoculative releases. In this paper, the cannibalistic behavior of two species of predatory bugs was studied under laboratory conditions-one of them a generalist predator (strictly carnivorous), Nabis pseudoferus, and the other a true omnivore (zoophytophagous), Nesidiocoris tenuis - and compared with the intraguild predation (IGP) behavior. The results showed that cannibalism in N. pseudoferus was prevalent in all the developmental stages studied, whereas in $N$. tenuis, cannibalism was rarely observed, and it was restricted mainly to the first three nymphal stages. Cannibalism and intraguild predation had no linear relationship with the different cannibal-prey size ratios, as evaluated by the mortality rates and survival times, although there were variations in cannibalism between stages, especially for N. pseudoferus. The mathematical model's implications are presented and discussed.
\end{abstract}

Keywords: Nabis pseudoferus; Nesidiocoris tenuis; predatory insect; generalist predator; true omnivore; intraguild predation; ontogeny; biological control; mathematical model

\section{Introduction}

Omnivores can be classified according to their diet or their role in ecological food webs [1]. Omnivory may be opportunistic, obligatory or facultative, based on the relative importance of plant and prey materials in the insect's diet. However, according to their ecological role in food webs, an omnivore that feeds on more than one trophic level is commonly termed a "trophic omnivore" [1]. Intraguild predation is an example of trophic omnivory in which a predator consumes other predators with whom it shares a common herbivore prey [1,2]. "True omnivory", therefore, is a particular case of trophic omnivory in which the consumer feeds on both plants and prey [1]. According to Hurd [3], generalist arthropod predators are typically bitrophic: they simultaneously occupy the third and fourth trophic levels by virtue of feeding both on herbivores and each other, i.e., they engage in intraguild predation (IGP).

At the same time, predation can be either between species or among individuals within the same species, since most generalist predators are cannibals [3]. Cannibalism occurs very frequently in nature and has been documented in more than 1300 species [4,5]. For many arthropods, cannibalism is a normal 
phenomenon, not an anomaly. Cannibalism has been documented in many insect orders, including Odonata, Orthoptera, Thysanoptera, Hemiptera, Trichoptera, Lepidoptera, Diptera, Neuroptera, Coleoptera and Hymenoptera. It occurs among predatory species and herbivores, involving predation by the mobile adults and larvae or nymphs on each other, and on immobile eggs and pupae [5,6]. There are many types of cannibalism, e.g., filial cannibalism as an energetic benefit [7]; sibling cannibalism [8,9] and intrauterine cannibalism in parasitoid insects [10], in which the cannibalism can increase the survival rate when food is scarce [11]; sexual cannibalism, in which a female insect cannibalizes her male mate during copulation [12]; cannibalism as competition [13]; or parasitizing offspring [5], etc.

In many systems, IGP and cannibalism occur together [14], and IGP is often associated with cannibalism $[15,16]$. Omnivory can be viewed as a strategy to reduce intraguild predation levels (and cannibalism) as it may allow omnivores to change locations and feed on plants under threat of predation [1].

From a practical point of view, the effects of IGP and cannibalism in biological pest control have received unequal attention. Many previous studies have been dedicated to the effects of IGP on the efficacy of natural enemies [17]. Most frequently, IGP is reported to be damaging or antagonistic [16-22] although it may sometimes have a neutral [23] or beneficial (synergistic) effect [24,25].The effect of cannibalism has received less modelling attention, which is curious since it is often associated with IGP. Moreover, it is an important impediment to efficiency in the mass production of biological control agents [26-31]. In addition, in augmentative biological control, releases can result in high densities of natural enemies at low pest levels, or before the pest appears on the crop [32]. Thus, cannibalism could exert an important influence on biological control outcomes [33-36]. Finally, because cannibalism is ubiquitous in food webs and frequent in systems where predator and prey share a common resource (IGP), its impacts on interspecific interactions and community dynamics and structure need to be better understood $[37,38]$.

Biological pest control systems are very complex, especially in greenhouse crops where various beneficial organisms may be employed at the same time (predators, parasitoids and entomopathogens) in the same crop cycle to control different phytophagous species [32]. In such systems, it becomes more important, and sometimes fundamental, to recognize all the ecological relationships because the success of the system may depend on this knowledge [25]. Information is limited on the effects of cannibalism regarding the efficacy of biological pest control in these systems when, for example, high densities of natural enemies are released in augmentative biological programs [39] or when the pest population is not present, or present only at a low density. At the same time, agro-ecosystems are usually modified to be simpler than natural ecosystems [40], involving fewer factors and fewer interactions, which could facilitate the interpretation of ecological relationships.

Nesidiocoris tenuis (Reuter) (Hem.: Miridae), an omnivorous species [41], was introduced into Europe [42,43] from an originally paleotropical distribution. The species feeds both phytophagously and zoophagously, and has been considered a crop pest [44,45]. Its prey range includes aphids, whitefly and eggs and larvae of small lepidopterans [46-49]. Conversely, Nabis pseudoferus Remane (Hem.: Nabidae) can be considered a generalist predator (a non-omnivorous species) [50]. The majority of the Nabidae studied also practice plant feeding but they are not able to develop in the absence of prey [51-53]. Plant feedings are believed to be for the purpose of water acquisition [54] and do little or no damage to the plant. This practice seems to help the predator to survive during prey scarcity [53]. $N$. tenuis is currently used as a biological control agent in tomato greenhouses to control the whitefly Bemisia tabaci (Gennadius) (Hem.: Aleyrodidae) and the tomato leaf miner Tuta absoluta (Meyrick) (Lep.: Gelechiidae) [32,39].

The other species, N. pseudoferus (Hem.: Nabidae), has a wide prey range and is considered to be an important predator of aphids [55,56], but also a voracious predator of lepidopterans and other groups of arthropods, including hemipterans and spider mites [57-60]. N. pseudoferus is also currently used as a biological pest control agent of lepidopterans in greenhouses crops [16,32]. 
According to the above and the types of omnivory mentioned above, N. tenuis is a "true omnivore" and N. pseudoferus is a "generalist predator".

The aim of this work was to study the importance of cannibalism in two species of predatory bugs with different feeding behavior that are often used in biological control programs. The cannibalism performed by each species was studied, both in the presence and absence of prey, in relation to their ontogeny under laboratory conditions, after which the IGP between both species was assayed under similar conditions. Cannibalism by the generalist predator was also studied under microcosm conditions.

\section{Materials and Methods}

\subsection{Ethics Statement}

The N. pseudoferus specimens were collected using a sweep net from alfalfa grown on private land after obtaining the owner's permission. The sampling methods, the collection of the experimental $N$. pseudoferus, the rearing under controlled conditions and the design and development of the experiments, etc.-for this species and the other insect species used in this work-agree with the Spanish and European legislation on the protection of animals used for scientific purposes, which exclude invertebrates/insects.

\subsection{Biological Material}

A colony of $N$. pseudoferus was established from a population collected in Pinos Puente $\left(37.248258^{\circ} \mathrm{N}, 3.765974^{\circ} \mathrm{W}\right)$ and Atarfe $\left(37.218402^{\circ} \mathrm{N}, 3.713381^{\circ} \mathrm{W}\right)$, Granada, Spain, and reared under laboratory conditions for 25 generations ( 3 years; 1.5 months/generation) before being used in the experiments. Every year new individuals collected at the same locations were added to the laboratory population to avoid inbreeding and loss of genetic variability. A colony of $N$. tenuis was established from material purchased from a commercial producer (Nesidiocontrol ${ }^{\circledR}$, Agrobio S.L., La Mojonera, Almeria, Spain) and reared in the lab for two generations before being used in the assays. Frozen eggs of Ephestia kuehniella Zeller (Lep.: Pyralidae), which were also used in the experiments, were purchased from a commercial supplier (Ephescontrol ${ }^{\circledR}$, Agrobio S.L., La Mojonera, Almeria, Spain) and stored at $-40{ }^{\circ} \mathrm{C}$ until use.

\subsection{Laboratory Trials}

Four laboratory assays, adapted from the methodology of Walzer and Shausberger [61] and Schausberger and Croft [62], were conducted under the physical conditions of $25 \pm 1{ }^{\circ} \mathrm{C}, 60-80 \%$ relative humidity $(\mathrm{RH})$ and a $16 \mathrm{~h}: 8 \mathrm{~h}$ light:dark photoperiod.

\subsubsection{Experimental Design and Procedures}

Seven-day-old adult females collected from the stock colony were assumed to be sexually mature and mated. Newly molted nymphal stages with hardened exoskeletons were selected to avoid presenting conspecifics during a vulnerable period of ecdysis [5]. All the individuals were isolated in plastic containers $(500 \mathrm{~mL})$ with a sponge $(2.0 \mathrm{~cm} \times 2.0 \mathrm{~cm} \times 0.2 \mathrm{~cm})$ moistened with distilled water and starved for $24 \mathrm{~h}$ prior to use in the assays. Individuals were then transferred to a new container in pairs, depending on the treatments described below, without refuge, water or food. The trials were performed over three days.

The treatments were as follows: (a) Cannibalism assay for N. pseudoferus: All 21 pairwise mathematical combinations, with repetitions and non-order from the following life stage/instar: adult female, V-, IV-, III-, II- and I-instar nymph (Table A1); (b) Cannibalism assay for N. tenuis: The treatments consisted of the same 21 combinations as above (Table A1); (c) N. pseudoferus-N. tenuis IGP-assay 1: In the hypergeometric distribution (in which selections are made from two subgroups without replacing members of the subgroup; this distribution differs from the binomial distribution in the lack 
of replacements) [63]: Subgroup 1 (6 elements): Adult female, V-, IV-, III-, II- and I-instar nymphs of N. pseudoferus, and Subgroup 2 (6 elements): adult female, V-, IV-, III-, II- and I-instars of N. tenuis, twenty-one pairs were chosen, as shown in Table A2, in which the two species were at the same or lower stage class; and (d) N. pseudoferus-N. tenuis IGP-assay 2: In the hypergeometric distribution in which there are two subgroups) that do not have elements in common: Subgroup 1 (5 elements): V-, IV-, III-, II- and I-instar nymphs of N. pseudoferus, and Subgroup 2 (5 elements): Adult female, V-, IV-, III- and II-instars of N. tenuis. Fifteen pairs were chosen, as shown in Table A3, in which N. pseudoferus was always in a lower stage class than $N$. tenuis.

Twenty repetitions were performed for each assay and treatment. All the assays were conducted identically on different days until all the treatments and repetitions were completed. We used the instantaneous sampling method $[64,65]$ to analyze the survival times of the individuals. Each container was observed for one minute (the sample point) every $30 \mathrm{~min}$ (the sample interval) until the sixth hour of the first day. If no individuals died, the procedure was performed again on the second day, and if there was still no reaction, the procedure was repeated on the third day.

Additionally, 20 adult females and 20 nymphs from each developmental stage (instars) were selected from the rearing populations, placed under the same conditions as before, mounted in alcohol and measured (length and width) using a micrometer under a binocular microscope.

\subsubsection{Statistical Analysis}

The cumulative survival times of the nymphal instars or adults, caged with either a conspecific or heterospecific, were analyzed using the Kaplan-Meier procedure [66,67]. This procedure is a method of estimating time-to-event models in the presence of censored cases. Within the Kaplan-Meier procedure, the equality of survival functions was compared with Breslow tests [68] using IBM SPSS version 25 software [69].

The mortality data were expressed as percentages, and survival times in hours. The data obtained in the cannibalism assay of N. pseudoferus and N. tenuis, as well as the values corresponding to IGP N. pseudoferus-N. tenuis, were adjusted to follow the non-linear (quadratic) regression:

$$
Y=a+b \cdot x+c \cdot x^{2}
$$

where $Y=$ the mortality or survival time and $x$ is the size ratio (the difference of the product of length $\mathrm{x}$ width of the predator minus the product of length $x$ width of the prey), expressed in $\mathrm{mm}^{2}$. The size difference parameter was used because, for many species, cannibalism and IGP are more related to size disparity than to absolute size [5]. The previous equation was adjusted by non-linear regression using the Statgraphics Centurion version 18 statistical software package [70].

\subsection{Microcosm Trials}

Regarding the high level of N. pseudoferus cannibalism found in previous trials, the starting hypothesis was to check whether the presence of alternative prey and refuge could significantly reduce such cannibalism. To test this hypothesis, two trials were conducted under microcosm conditions to evaluate filial and sibling cannibalism as a function of the predator developmental stage and prey density.

\subsubsection{Experimental Design and Procedures}

The two trials were performed with individuals selected from the lab stock colony of N. pseudoferus, using the same procedure as described above. Individuals were isolated in $500 \mathrm{~mL}$ plastic containers (as above) and starved for $24 \mathrm{~h}$ prior to the assays, after which the individuals were transferred to a new plastic container $(40.0 \mathrm{~cm} \times 30.0 \mathrm{~cm} \times 21.0 \mathrm{~cm}$; used as a microcosm $)$. The containers had two holes on the top $\left(5.0 \mathrm{~cm}\right.$ in diameter) covered with mesh. One tomato plant, cv Vernal ${ }^{\circledR}$, Enza Zadem (ca. $23 \mathrm{~cm}$ high, with 7-8 leaves), was included in each container. E. kuehniella eggs were used as 
prey and they were always provided in the same way to avoid prey search problems, and conflicts between conspecifics, as well as to ensure uniform distribution, as described below. The E. kuehniella eggs were adhered with water to a $15 \mathrm{~cm}$-long portion of sisal rope. To ensure the correct prey weight, all the ropes were weighed with precision scales before and after the trial. The rope pieces with the E. kuehniella eggs attached were then entwined around the plant stem to eliminate any predator in one location. Nabis adults are known to prefer the upper parts of the plant (inside the plant canopy) while the immature stages tend to stay lower down on the plant, outside the canopy [71,72].

The factorial design used a single factor at two levels: (1) the presence or absence of adult females, and (2) the E. kuehniella prey density. Each treatment was repeated four times.

In the first trial, 10 I-instar nymphs were placed in each container, whereas in the second assay, there were five III-instar nymphs per container. The same prey densities were used as in the first assay: 0, 0.006, 0.011 and $0.040 \mathrm{~g} /$ day; and in the second assay: 0, 0.011, 0.040 and $0.080 \mathrm{~g} /$ day.

Both trials were performed at $25 \pm 2{ }^{\circ} \mathrm{C}, 60-80 \% \mathrm{RH}$ and a 16:8 L:D photoperiod. The containers were examined daily for E. kuehniella prey replenishment, and the developmental stage of the predators was checked. The first assay was terminated when $50 \%$ of the nymphs molted to the III-instar. Similarly, the second assay ended when $50 \%$ of the nymphs reached the adult stage. The number of individuals surviving to the end of the assay was then recorded. In addition, the females used in the second microcosm assay were previously marked [73]: A dot of 0.4 pigment liner (art. no.: 308 04-9, Staedtler ${ }^{\circledR}$, Nuremberg, Germany) was applied to each quadrant of the pronotum.

\subsubsection{Statistical Analysis}

The survival percentages were subjected to a generalized linear model (GZLM) analysis using IBM SPSS version 25 software [69]. The models were fitted by maximum quasi-likelihood estimation using the GenLin procedure with normal errors and the identity function. In each trial, the significance of the model was assessed with an Omnibus test (to test whether the explained variance in a data set is significantly greater overall than the unexplained variance). For each regression effect specified in the model, a Wald statistical test was carried out, which is based on the linearly independent pairwise comparisons among the estimated marginal means. Then, the mean values were compared pairwise, with significance indicated at $p=0.05$.

To order to estimate the nymph mortality specifically due to cannibalism by adult females, the Henderson-Tilton equation [74] was applied:

$$
M_{C}=\frac{M_{t}-M_{t}^{\prime}}{100-M_{t}^{\prime}} * 100
$$

where $M_{C}$ is the corrected percentage of mortality due to adult females, $M_{t}$ is the percentage of nymphal mortality in the presence of adult females at the end of the assay and $M^{\prime}{ }_{t}$ is the percentage of nymphal mortality in the absence of adult females at the end of the assay.

\section{Results}

\subsection{Stage Structure}

The size of $N$. pseudoferus, especially the length, increased from $1.84 \pm 0.04 \mathrm{~mm}$ for the first instars to $7.11 \pm 0.06 \mathrm{~mm}$ in adult females, while in $N$. tenuis, it increased from $0.96 \pm 0.03 \mathrm{~mm}$ to $3.12 \pm 0.02$ $\mathrm{mm}$ (Figure 1). In contrast, only the last nymph instars (IV- and I-instars) and adult females of N. tenuis had the same or greater size than the first nymphal instars of N. pseudoferus (I- and II-instars). 


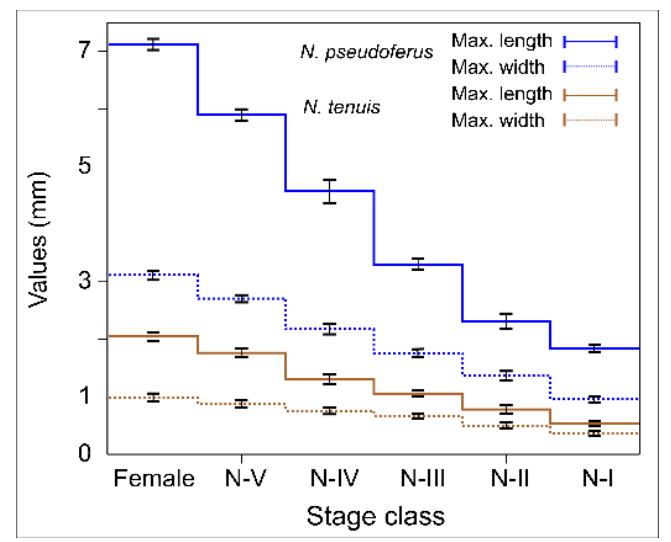

Figure 1. Average maximum lengths and widths $(\mathrm{mm} \pm \mathrm{SE})$ of Nabis pseudoferus and Nesidiocoris tenuis according to their post-embryonic development.

\subsection{Laboratory Trial 1: N. pseudoferus Cannibalism}

Cannibalism by N. pseudoferus in the absence of prey was very high in all nymphal instars and adult females (Figure 2). The average survival of all the bugs was quite low (41.7\%). Higher values were only observed when both conspecifics were in the same developmental stage. Average survival increased from $11.7 \%$ for first instars to $65.0 \%$ for adult females.

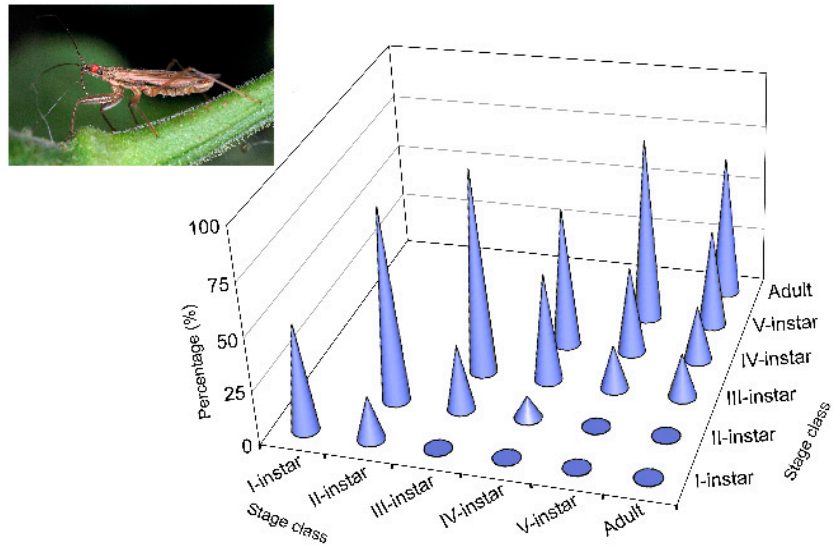

Figure 2. Survival (\%) from Nabis pseudoferus cannibalism by life stage when caged with other conspecifics of the same or lower stage class, over $72 \mathrm{~h}$, under laboratory conditions $\left(25 \pm 1{ }^{\circ} \mathrm{C}\right.$ and $60-80 \% \mathrm{RH})$ without prey.

The Kaplan-Meier procedure revealed significant differences within the treatments (Breslow test, generalized Wilcoxon $\chi^{2}=68.925, \mathrm{df}=5, p<0.0001$ ) (Table A4). Except for one case, the differences in the survival time were all significant, indicating high levels of cannibalism, but with somewhat different values. For all stages, the average survival time was $38.05 \pm 1.38 \mathrm{~h}$, just over half the experimental time limit $(72 \mathrm{~h}$ ). The survival time increased from $23.17 \pm 2.02 \mathrm{~h}$ for the I-instars to $63.00 \pm 2.91 \mathrm{~h}$ for adult females. The highest survival times were observed when conspecifics from the same developmental stage were paired. Lower survival times were observed when first and second instar nymphs were paired with later developmental stages.

The mortality and survival time adjusted for the size ratio are shown in Figure A1a,b. The values for the $a, b$ and $c$ parameters were $34.32 \pm 7.51,12.29 \pm 3.36$ and $-0.60 \pm 0.27$, and $57.75 \pm 4.66$, $-6.70 \pm 2.08$ and $0.28 \pm 0.17$ for the mortality and survival time, respectively. Both models were highly significant ( $F=15.03, \mathrm{df}=2, p=0.001$; and $F=15.32, \mathrm{df}=2, p=0.001$, respectively). One could observe that prey mortality (in smaller sizes) increased with an increasing size difference between the conspecifics. In other words, the survival time decreased with an increasing size disparity. 


\subsection{Laboratory Trial 2: N. tenuis Cannibalism}

In contrast to $N$. pseudoferus, N. tenuis showed a lower level of cannibalism (Figure 3). The average survival time for all stages was $82.6 \%$, almost double that of $N$. pseudoferus. The survival percentage was lower for the I-instars $(61.0 \%)$ and it increased up to $100 \%$ for adult females. The lowest survival percentages were lower than the average of the I- to III-instar nymphs from the same developmental stages (Figure 3). Additionally, unlike the other species, the most developed nymphal stages and the adult females exhibited little or no more cannibalism than the first instars.

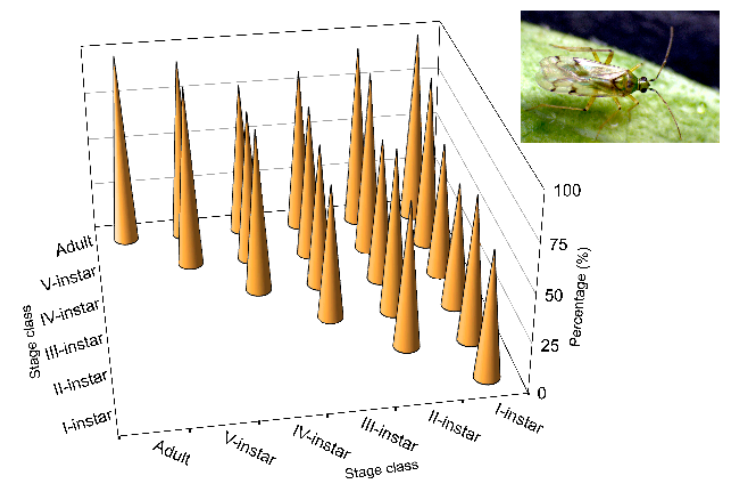

Figure 3. Survival (\%) from Nesidiocoris tenuis cannibalism by life stage when caged with other conspecific of the same or lower stage class, over $72 \mathrm{~h}$, under laboratory conditions $\left(25 \pm 1{ }^{\circ} \mathrm{C}\right.$ and $60-80 \% \mathrm{RH})$ without prey.

The aggressiveness of $N$. tenuis in relation to its conspecifics, measured as survival time (Table A5), was also very low, with an average value of $63.19 \pm 0.95 \mathrm{~h}$ over the $72 \mathrm{~h}$ trial time. Despite the overall comparison in the Kaplan-Meier procedure, significant differences between treatments were found (Breslow test, generalized Wilcoxon $\chi^{2}=11.443, \mathrm{df}=5, p<0.043$ ) for the adult females by comparing the strata or pair-only differences. The data found in the $N$. tenuis trial in the absence of prey or a food source (e.g., the plant) demonstrated very low cannibalistic behavior.

Figure A2a,b shows the nonlinear adjustments of mortality and victim survival in response to $N$. tenuis cannibalism. The values for the $a, b$ and $c$ parameters were $16.16 \pm 3.53,18.89 \pm 9.16$ and -10.54 \pm 4.15 , and $63.42 \pm 1.77,-8.85 \pm 4.57$ and $5.26 \pm 2.07$, respectively. In this case, the model's adjustments to mortality and survival time were significant $(F=4.16, \mathrm{df}=2, p=0.0328$; and $F=4.87, \mathrm{df}=2, p=$ 0.0204, respectively).

\subsection{Laboratory Trial 3: IGP N. pseudoferus-N. tenuis Assay 1}

From the overall comparison in the Kaplan-Meier procedure, it was determined that there were significant differences between treatments (Breslow test, generalized Wilcoxon $\chi^{2}=74.582, \mathrm{df}=5$, $p<0.0001)$.

Table A6 shows the aggressiveness of N. pseudoferus when paired with N. tenuis individuals at the same developmental stage. The average survival time values were very short compared with those observed for N. pseudoferus in the cannibalism assay (Table A4). The average time of the trials was $16.04 \pm 0.60 \mathrm{~h}$, which was less than one-quarter of the exposure time (72 h). The low survivorship time of $N$. tenuis adults in the presence of $N$. pseudoferus adult females was notable (Table A6), with a value of $3.53 \pm 1.43 \mathrm{~h}$, which was very significant compared to the other values. This might be because the higher prey mobility (due to wings) encourages more intensive predation by N. pseudoferus females. However, the survival time for $N$. tenuis I-instars seems to be very similar to that observed for N. pseudoferus I-instars (Table A4), indicating that adult females of both species were equally aggressive toward first instars.

The failure of any N. tenuis stages to survive $72 \mathrm{~h}$ indicates that $N$. tenuis is prey for N. pseudoferus. There was no mortality of any N. pseudoferus stage as a result of $N$. tenuis predation. Thus, another IGP 
trial was carried out, as described in the following section, to evaluate the IGP when N. pseudoferus was always in a lower stage class than $N$. tenuis.

\subsection{Laboratory Trial 4: IGP N. pseudoferus-N. tenuis Assay 2}

Due to the very low survival of N. tenuis as IGP-prey in relation to the actions of N. pseudoferus as an IGP-predator (as indicated in the previous section), a second trial was carried out in which the size differences between the two species were smaller. There were significant result differences between treatments (Breslow test, generalized Wilcoxon $\chi^{2}=280.776$, $\mathrm{df}=1, p<0.0001$ ) for the overall comparison in the Kaplan-Meier procedure (Table A7). The mean survival time of the different $N$. pseudoferus stages was $68.76 \pm 1.15 \mathrm{~h}$ compared to $35.23 \pm 0.74 \mathrm{~h}$ for $N$. tenuis. This last value is much higher that found for this species in the previous trial.

The survival of N. pseudoferus in the V-and IV-instars was $100 \%$, but it was slightly lower in the earlier stages (70-100\%) (Figure 4). Conversely, the survival of N. tenuis was low (Figure 4), but higher than in the previous trial, in which no individuals survived to the end of the assay. The results as a whole lead us to say that, in terms of IGP, size differences are very important, as indicated in the cannibalism trials.

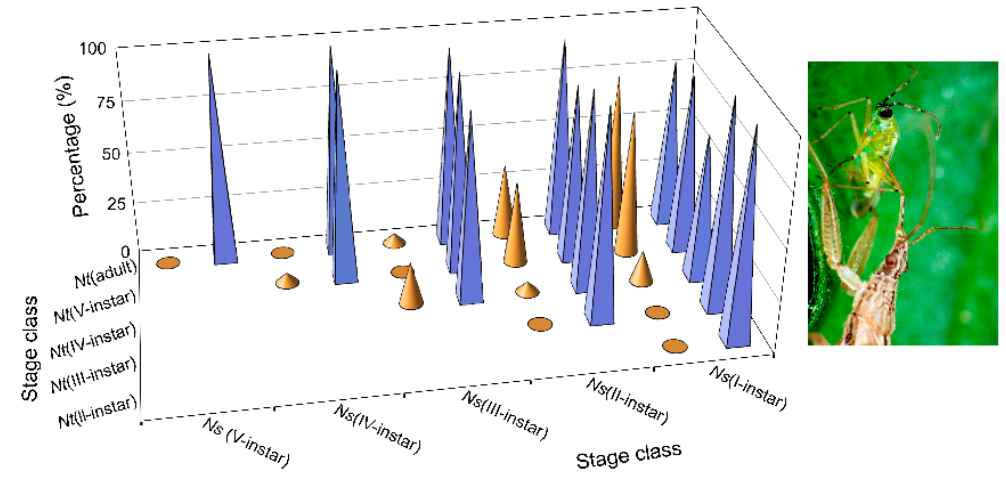

Figure 4. Stage-specific survival (\%) of Nesidiocoris tenuis (brown cone, $\mathrm{Nt}$ ) and Nabis pseudoferus (blue pyramid, Ns) in intraguild competition (IGP) when caged singly with the other species for $72 \mathrm{~h}$ under laboratory conditions $\left(25 \pm 1{ }^{\circ} \mathrm{C}\right.$ and $\left.60-80 \% \mathrm{RH}\right)$ without prey, and when $N$. pseudoferus was always in a lower stage class than $N$. tenuis.

It has to be pointed out that N. pseudoferus I-instar aggressiveness towards N. tenuis II-instars (19.38 $\pm 1.81 \mathrm{~h}$ ) (Table A7) is similar to that of N. pseudoferus I-instars towards N. tenuis I-instars $(20.60 \pm 1.60 \mathrm{~h})$ (Table A3), although both of the values were substantially lower than that found in I-instar cannibalism for N. pseudoferus $(43.60 \pm 6.58 \mathrm{~h}$ ) (Table A4). This seems to indicate the cannibalistic intensity, which was lower in this stage than in the non-conspecific.

The model adjusted to the $N$. tenuis mortality percentage and survival time, as the data of the two former assays (IGP), is shown in Figure A3a,b. At the same time, the parameter values $a, b$ and $c$ were $80.04 \pm 3.37,7.25 \pm 1.47$ and $-0.46 \pm 0.12$, and $34.61 \pm 2.04,-4.95 \pm 0.90$ and $0.26 \pm 0.07$ for the mortality and the survival time, respectively. The same was true for N. pseudoferus cannibalism, as the IG predation produced an increase in mortality and a decrease in the survival time for the IG prey, with an increase in the size differences between them in both cases.

\subsection{Microcosm Trials: Effects of the Prey Density}

\subsubsection{N. pseudoferus Cannibalism in the I- to III-Instars}

Figure 5a shows the survival percentage for the N. pseudoferus nymphs (I- to III-instars), depending on prey density, and the presence or absence of adult females. The GZLM analysis showed that the model was highly significant (likelihood ratio $\chi^{2}=45.431, \mathrm{df}=7, p<0.0001$ ). The presence of adult 
females (likelihood ratio $\chi^{2}=20.998$, $\mathrm{df}=1, p<0.0001$ ), prey density (likelihood ratio $\chi^{2}=33.356$, $\mathrm{df}=3, p<0.0001$ ) and interactions (likelihood ratio $\chi^{2}=10.134$, $\mathrm{df}=3, p=0.0170$ ) had significant effects on nymphal survival. Survival was zero in the absence of prey and increased with prey density. Similarly, the survival of nymphs was lower in the presence of adult females than in their absence for prey densities 1, 2 and 3, respectively (Figure 5a). However, there were no significant differences in nymphal survival at densities 1,2 and 3 in the absence of adult females, nor in the presence of adult females at high prey densities (Figure 5a).

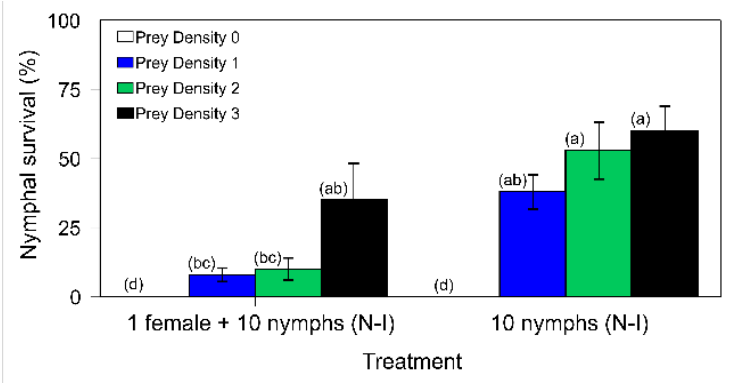

(a)

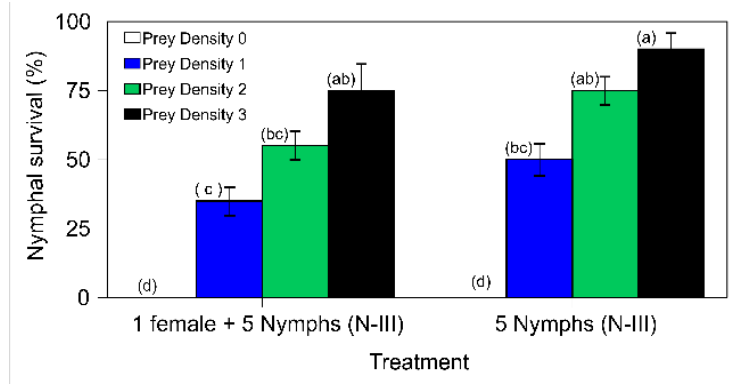

(b)

Figure 5. Survival (\%) $( \pm \mathrm{SE})$ of the Nabis pseudoferus instars: (a) N-I to N-III) or (b) N-III to adult in the presence or absence of an adult female, according to the prey density. The microcosm trial was performed using tomato plants under laboratory conditions $\left(25 \pm 2{ }^{\circ} \mathrm{C}\right.$ and $\left.60-80 \% \mathrm{RH}\right)$. In each figure: the values with different superscript letters ( $a, b, c$, and $d)$ in a column are significantly different $(p<0.05)$.

\subsubsection{N. pseudoferus Cannibalism in the III-Instar to Adult Stages}

For nymphs in a more advanced developmental stage (III-instar to adult), the GZLM analysis showed the model was highly significant (likelihood ratio $\chi^{2}=80.823, \mathrm{df}=7, p<0.0001$ ). The presence of adult females (likelihood ratio $\chi^{2}=11.811, \mathrm{df}=1, p<0.001$ ) and prey density (likelihood ratio $\left.\chi^{2}=79.230, \mathrm{df}=3, p<0.0001\right)$ had significant effects on survival, with no significant interaction between both factors (likelihood ratio $\chi^{2}=10.134$, $\mathrm{df}=3, p=0.190$ ).

The nymphal survival for prey densities 1, 2 and 3 (the III-instar to adult trial) in the absence of adult females was $50.0 \% \pm 5.8 \%, 75.0 \% \pm 5.0 \%$ and $90.0 \% \pm 5.8 \%$, respectively, and this was lower in the presence of females, $35.0 \% \pm 5.0 \%, 55.0 \% \pm 5.0 \%$ and $75.0 \% \pm 9.6 \%$, respectively (Figure $5 b$ ). There were no significant differences in nymphal survival for each prey dose evaluated (1,2 and 3) in the presence or absence of adult females. Therefore, compared to the previous trials, these values seem to indicate that, at the initial developmental stages of N. pseudoferus (the I- to III-instar trial) in the presence of different prey doses, there is a higher incidence of adult female cannibalism than in the later nymphal developmental stages, as shown in the previous cannibalism trials. Using the Henderson-Tilton equation, the mortality values for adult female cannibalism were $79.0 \%, 81.1 \%$ and $41.7 \%$ in the first microcosm assay, and $30.0 \%, 26.7 \%$ and $16.7 \%$ in the second, for prey densities 1 , 2 and 3, respectively. Thus, in the presence of plant and prey, most cannibalism is carried out by adult females.

\section{Discussion}

The predatory species N. pseudoferus, which feeds on food sources from more than one trophic level, may be considered "trophic omnivorous", according to Coll and Guershon [1]. It is considered a generalist predator; however, with regard to the diversity of taxonomical groups attacked, it is more specialist than other generalist predators, for instance, spiders, which are able to feed on several trophic levels [50]. N. pseudoferus was strongly cannibalistic when prey was absent. Individuals in the later developmental stages performed more acts of cannibalism, especially adult females. The results are within the general rule for cannibalism [5]. In contrast, the cannibalism rate for the omnivorous species 
$N$. tenuis was substantially lower; this is a "true omnivore", following the terminology of Coll and Guershon [1], a particular case of trophic omnivory in which the consumer feeds on both plants and prey. For this species, the same nymphal instars (I, II and, to a lesser extent, III) were cannibalized by conspecifics of the same developmental stage (sibling cannibalism) (Figure 3 and Table A4). All of this serves to differentiate the two species. It also means that cannibalism in N. tenuis is an exception to the general rule of cannibalism, in which the largest (and older) individuals commit more acts of cannibalism than the smaller (and younger) individuals. This is similar to other exceptions cited in other species, such as certain species of fish, dragonfly larvae and parasitoid larvae that are more cannibalistic when smaller (younger) [5].

There are few studies published studies on cannibalism in Nabis species, with the exception of the studies performed on the American species N. alternatus Parshley [75,76], as well as on the European species Himacerus apterus F. [77]. The observed results regarding the incidence of cannibalism in N. pseudoferus are larger than those cited for N. alternatus.

On the other hand, the cannibalism rate for N. pseudoferus in the absence of prey is comparable to those cited in spiderlings of several wolf spider species [4,78,79]. However, in other species of this spider group, the cannibalism rate is lower [80,81].

In relation to other arthropod groups, the values found for N. pseudoferus were similar to those cited for larvae preyed upon by adult females in some species of predatory mites (Acari: Phytoseiidae) [62].

Cannibalism in N. pseudoferus, as commented on before, is very important and seems to be closely related to the absence of prey, as well as to size differences between the victim and the predator, as can be observed in the mortality percentages (Figure A1a) and survival times for the different developmental stages studied (Figure A1b). The importance of size differences in cannibalism has been cited and widely documented for scorpions $[5,82]$, spiders $[8,79,82,83]$ and predatory coccinellids $[84,85]$, as well as for other invertebrate and vertebrate species [86,87]; however, it has seldom been studied in insects, with the exception of the work by Laycock et al. [88].

Analyzing the importance of size differences in N. pseudoferus cannibalism in more detail, for some species (e.g., fish or wolf spiders), it was reported that there is a predator-prey size difference threshold at which cannibalism takes place [5,83]; this does not seems to be the case in N. pseudoferus. However, only the papers by Polis $[5,86]$ have studied size and cannibalism in detail. Polis [86] found that the relationship between size (size ratio: larger/smaller) and cannibalism was linear in desert scorpions. However, for N. pseudoferus, the relationship between size and cannibalism, whether the mortality percentage or the survival time, are not linear. The differences could be due, at least in part, to differences in development and life-cycle duration, as in the scorpion species studied, e.g., Paruroctonus mesaensis (Stahnke), which has a life cycle $>60$ months compared to the short developmental period of N. pseudoferus (30 days; unpublished data), and in part due to different predation behavior.

A nonlinear relationship between the mortality, or the survival time, and the size ratio was found in N. pseudoferus (Figure A1a,b), which seems to be because of two effects: size differences and developmental stages, given that size differences are fundamental for cannibalism to occur. However, cannibalism is also influenced by the developmental stage of the predator, as can be observed from the survival percentages and survival times (Figure A1a,b). Therefore, cannibalism varies with the different developmental stages of N. pseudoferus, as measured in the survival percentage and the survival time.

The cannibalism results for $N$. tenuis show very low rates in the absence of prey or other food sources (e.g., plants), and in the absence of water. These results accord with those of Moreno-Ripoll et al. [89] for I- and II-instars of the same species in the absence of prey, although these authors reported different cannibalism results for adult females. In our work, there was no case of cannibalism between adult females whereas these authors did cite adult female cannibalism. The differences could be explained by the higher densities of female used by these authors. A higher density increases the number of encounters, and thus more cannibalism occurs [5,82]. Additionally, the survival values for $N$. tenuis in the presence of conspecifics are similar to those found in Macrolophus pygmaeus Wagner (Hem.: Miridae) [90]. 
Higher values of $N$. tenuis cannibalism for were observed (Figure 3) in the first three nymphal instars, performed by conspecifics at the same stages, as mentioned above. It should be noted that these $N$. tenuis nymphal instars have a higher degree of phytophagy. Thus, the I-instars of the species are able to survive until they become III-instars by feeding only on plant material [91-93]. In contrast to the III-instars, the species shows greater zoophagy [91]; this is contrary to the results that showed reduced cannibalism at that stage and at subsequent stages. Perhaps in the first three instars, cannibalism is not caused by the need to eliminate potential competitors, as cited for other species $[4,5,14,85,94]$.

The results showing low levels of cannibalism in omnivorous $N$. tenuis suggest that omnivores sustain themselves on plant sources in the absence of prey without the need to resort to cannibalism, as stated by Leon-Beck and Coll [95]. Moreover, their potential as a phytophagous species, as observed in our results, is opposite to that reported by Bernays [96] for cannibalism in phytophagous insects, suggesting that in this group of insects, cannibalism is more common among generalist than specialist herbivores.

For $N$. tenuis, despite finding weak cannibalism, we also established a nonlinear relationship between the mortality percentage or survival time, and the size differences between the predator and the victim (Figure A2a,b); this contrasts with N. pseudoferus, where we found cannibalism differences occurring at low to intermediate sizes. This would suggest that cannibalism is more influenced by behavior, mainly of the early instars, than the size differences of the conspecifics.

In this work, the differences between N. pseudoferus and N. tenuis in the cannibalism rate and the attack stage, when both species share the same ecological niche [97], could be due to their different diets: N. pseudoferus is a "non-omnivorous predator" and N. tenuis is a "true omnivore". Thus, in the absence of prey, $N$. pseudoferus cannot opt for any other food source than cannibalism whereas under the same circumstances, $N$. tenuis can choose to feed phytophagously. In contrast, omnivory could be a strategy to reduce IGP levels (and cannibalism) as it allows omnivores to change their location and to feed on plants in the presence of other predators [1].

From the IGP trial results, N. pseudoferus acts as an IG predator and kills N. tenuis as IG prey (Figure 4). It is an asymmetrical relationship in favor of the former species, depending on the size differences between the species (Figure 1). This confirms the work of Polis et al. [14], which states that relative body size and the degree of trophic specialization are the two most important factors influencing IGP frequency and direction. Most IGP occurs in systems with size-structured populations and is carried out by generalist predators who are usually larger than their intraguild prey. Many of these IG predators also cannibalize smaller conspecifics.

By studying N. tenuis predation at different developmental stages by N. pseudoferus in the two IGP tests performed, we can observe that both the survival percentage and the survival time are strongly influenced by size differences between the predator and prey (Figure A3a,b; Tables A6 and A7)—this is known to happen in cannibalism, and has been shown, not only in our results, but also in numerous other studies $[5,14,76,98,99]$.

However, in the present study, we found exceptions to the above relationship of size and IGP. In general, the different $N$. tenuis developmental states are smaller in size than those of N. pseudoferus, except for the adult stage of the N. tenuis, which is very similar to the III-instar state of N. pseudoferus (and larger than the I- and II-instars), whereas the V-instars of N. tenuis are larger than the I- and II-instars of N. pseudoferus (Figure 1). Despite these size differences, similar survival percentages and survival times were observed for $N$. tenuis adult females paired with I-instars of N. pseudoferus (Figure 3 and Table A7). In the other cases where there was an equal or smaller size, N. pseudoferus predated $N$. tenuis. This may be motivated (in the absence of molting individuals) by the fact that, for smaller or same-sized individuals, N. pseudoferus exhibits better-suited predatory behavior for capturing and killing than does $N$. tenuis. We know that Nabis species inject venom into their prey $[100,101]$ and/or have better morphological adaptations (raptorial forelegs) [102] (Figure 2), characteristics that are not present in the other species. Such behavior in predatory Nabis species was observed when they were attacking larger, phytophagous species (e.g., Spodoptera exigua (Hübner), Lep.: Noctuidae) [103]. 
The importance of the presence of prey and refuge (the plant) in the N. pseudoferus cannibalism has been underscored in both microcosm assays (Figure $5 \mathrm{a}, \mathrm{b}$ ). This had already been cited in numerous studies on the presence and density of prey $[9,34,84]$ and refuge $[4,19]$. However, in such circumstances, the filial cannibalism level of N. pseudoferus is still very high, especially by adult females on the first instars (I- to III-instars) (Figure 5a), more so than on the later stages (III to V-instars) (Figure 5b). This could explain the location of individuals within the plant. In the absence of other predatory species, the females lay eggs mostly into the leaf petioles spread out equally over the height of the plant [104]. Moreover, Nabis adults prefer to sit on the top or slightly lower in the plant canopy, while immature individuals are found lower down in the plant [71,72].

Insects and other arthropods, unlike vertebrate species, have complex life cycles in which the successive stages may differ more dramatically, both in physical appearance and in their ecological role [105-108]. The findings from the two species studied indicate that cannibalism depends not only on the species, but also on their stage structure. Most ecological models in contemporary ecological theory ignore the implications of the age and size variation, particularly within populations. This is also true for empirical studies, both experimental and non-experimental [38]. However, recent studies show that stage structure can modify the dynamics of consumer-resource communities owing to stage-related shifts in the nature and strength of the interactions that occur within and between populations [108]. Consequently, these results can help to develop mathematical models based on stage structure, by considering a more realistic species ontogeny. Furthermore, and from the applied standpoint, the results of this study also highlight the importance of cannibalism, and its repercussions, in current biological control systems.

\section{Conclusions}

1. The diet, whether strictly carnivorous or omnivorous, seems to have a marked effect on the cannibalism of the two species studied. This could be extended to other insect species.

2. Ontogenetic development in insects with a stage structure doubly influences the cannibalism and the intra-guild predation (IGP) by affecting both the individual prey and the predator.

3. The ratio of predator-prey size in relation to the rate of cannibalism and intra-guild predation (IGP) is not a linear relationship, as has already been pointed out in the literature on arthropods.

4. These findings can help to develop mathematical models based on stage structure, by more realistically considering species with this type of ontogeny.

5. From an applied standpoint, these study results also highlight the importance of cannibalism, and its repercussions, in current biological control systems for pest species.

Author Contributions: Conceptualization, J.G. and T.C.; data curation, F.J.F.; investigation, F.J.F. and T.C.; methodology, F.J.F. and T.C.; resources, F.J.F.; software, M.G.; supervision, M.G. and T.C.; visualization, M.G.; writing—original draft, J.G. and T.C.; writing—review and editing, J.G. and T.C. All authors have read and agreed to the published version of the manuscript.

Funding: This research received no external funding.

Conflicts of Interest: The authors declare no conflict of interest. 


\section{Appendix A}

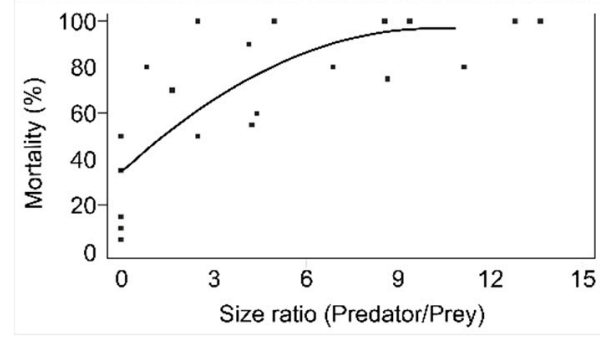

(a)

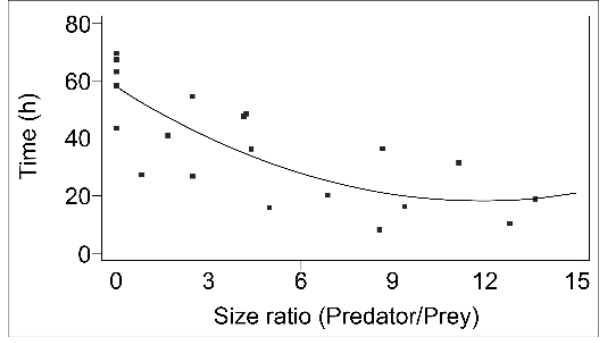

(b)

Figure A1. Relationship between mortality (\%) (a) and survival time (h) (b) of Nabis pseudoferus as a function of the size ratio between cannibal and prey.

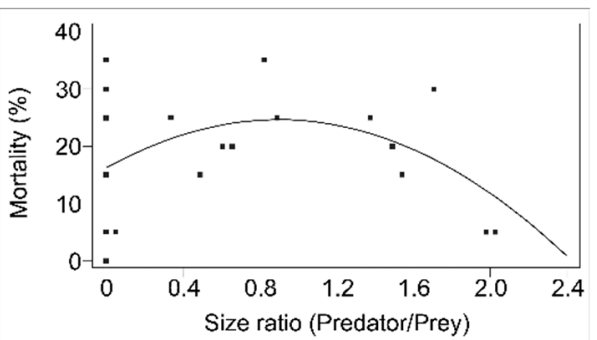

(a)

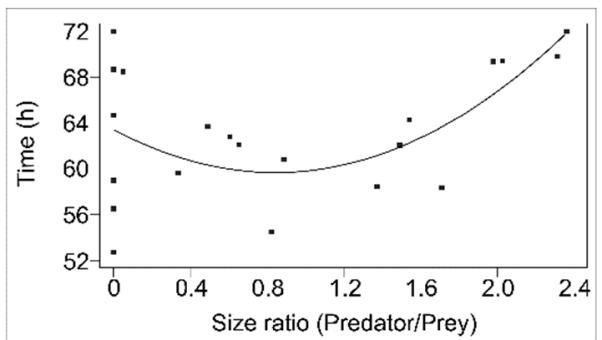

(b)

Figure A2. Relationship between mortality (\%) (a) and survival time (h) (b) of Nesidiocoris tenuis as a function of the size ratio between cannibal and prey.



(a)

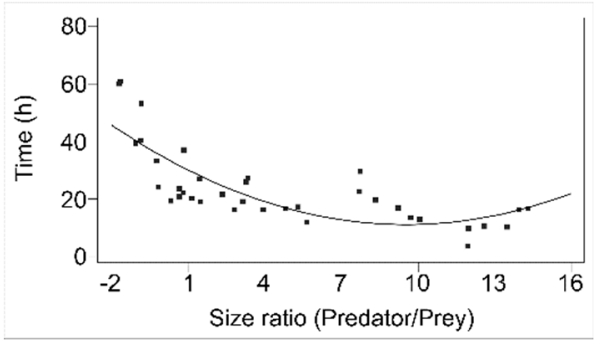

(b)

Figure A3. Relationship between mortality (\%) (a) and survival time (h) (b) in the predation of Nesidiocoris tenuis by Nabis pseudoferus, depending on the size ratios between prey-predator, when $N$. pseudoferus was always in a lower stage class than $N$. tenuis.

Table A1. Combinations used in cannibalism assays for N. pseudoferus and N. tenuis under laboratory conditions and without alternative prey.

\begin{tabular}{cccccc}
\hline \multicolumn{5}{c}{ Combinations } \\
\hline Adult-Adult & - & - & - & - & - \\
\hline Adult-NV & NV-NV & - & - & - & - \\
Adult-NIV & NV-NIV & NIV-NIV & - & - & - \\
Adult-NIII & NV-NIII & NV-NIII & NIII-NIII & - & - \\
Adult-NII & NV-NII & NV-NII & NIII-NII & NII-NII & - \\
Adult-NI & NV-NI & NV-NI & NIII-NI & NII-NI & NI-NI \\
\hline
\end{tabular}


Table A2. Combinations used in the IGP N. pseudoferus-N. tenuis, assay 1, under laboratory conditions and without alternative prey, when both predatory species are in the same or lower stage class.

\begin{tabular}{cccccc}
\hline \multicolumn{5}{c}{ Combinations } \\
\hline N.s.-N.t. & N.s.-N.t. & N.s.-N.t. & N.s.-N.t. & N.s.-N.t. & N.s.-N.t. \\
\hline Adult-Adult & - & - & - & - & - \\
Adult-NV & NV-NV & - & - & - & - \\
Adult-NIV & NV-NIV & NIV-NIV & - & - & - \\
Adult-NIII & NV-NIII & NV-NIII & NIII-NIII & - & - \\
Adult-NII & NV-NII & NV-NII & NIII-NII & NII-NII & - \\
Adult-NI & NV-NI & NV-NI & NIII-NI & NII-NI & NI-NI \\
\hline
\end{tabular}

NV, NIV, NIII, NII and NI: instars. N.s. = Nabis pseudoferus, N.t. = Nesidiocoris tenuis.

Table A3. Combinations used in the IGP N. pseudoferus-N. tenuis, assay 2, under laboratory conditions and without alternative prey, when N. pseudoferus was always in a lower stage class than N. tenuis.

\begin{tabular}{ccccc}
\hline \multicolumn{5}{c}{ Combinations } \\
\hline N.s.-N.t. & N.s.-N.t. & N.s.-N.t. & N.s.-N.t. & N.s.-N.t. \\
\hline NI-Adult & NII-Adult & NIII-Adult & NIV-Adult & NV-Adult \\
NI-NV & NII-NV & NIII-NV & NIV-NV & - \\
NI-NIV & NII-NIV & NIII-NIV & - & - \\
NI-NIII & NII-NIII & - & - & - \\
NI-NII & - & - & - & - \\
\hline
\end{tabular}

NV, NIV, NIII, NII and NI: instars. N.s. = Nabis pseudoferus, N.t. = Nesidiocoris tenuis. 
Table A4. Aggressiveness of Nabis pseudoferus cannibalism on different stage class, measured as survival time (hours) ( \pm SE) when caged singly with other conspecifics for $72 \mathrm{~h}$ under laboratory conditions $\left(25 \pm 1{ }^{\circ} \mathrm{C}\right.$ and $\left.60-80 \% \mathrm{RH}\right)$ and without prey.

\begin{tabular}{|c|c|c|c|c|c|c|c|c|c|c|c|c|c|c|c|}
\hline \multirow{3}{*}{ Stage } & \multicolumn{15}{|c|}{ Significance Level ( $p$ ) (Breslow Test) } \\
\hline & \multicolumn{2}{|c|}{ Adult } & \multicolumn{2}{|c|}{$\mathrm{N}-\mathrm{V}$} & \multicolumn{2}{|c|}{ N-IV } & \multicolumn{2}{|c|}{ N-III } & \multicolumn{2}{|c|}{ N-II } & \multicolumn{2}{|c|}{ N-I } & \multirow{2}{*}{$x^{2}$} & \multirow{2}{*}{ df } & \multirow{2}{*}{$p^{2}$} \\
\hline & Value & $p^{1}$ & Value & $p^{1}$ & Value & $p^{1}$ & Value & $p^{1}$ & Value & $p^{1}$ & Value & $p^{1}$ & & & \\
\hline Adult & $63.0 \pm 2.9$ & - & $48.5 \pm 5.7$ & 0.065 & $36.5 \pm 5.8$ & 0.001 & $31.5 \pm 5.6$ & 0.0001 & $10.3 \pm 2.5$ & 0.0001 & $19.08 \pm 2.4$ & 0.0001 & 59.614 & 5 & 0.001 \\
\hline N-IV & & & & & $58.3 \pm 4.4$ & - & $54.5 \pm 4.3$ & 0.6520 & $47.9 \pm 3.6$ & 0.0290 & $16.0 \pm 2.7$ & 0.0001 & 68.335 & 3 & 0.001 \\
\hline N-III & & & & & & & $69.7 \pm 2.3$ & - & $41.01 \pm 5.8$ & 0.0001 & $26.9 \pm 3.8$ & 0.0001 & 30.974 & 2 & 0.001 \\
\hline N-II & & & & & & & & & $67.5 \pm 3.0$ & - & $27.4 \pm 5.7$ & 0.0001 & 21.375 & 1 & 0.001 \\
\hline N-I & & & & & & & & & & & $43.6 \pm 6.6$ & - & - & - & - \\
\hline
\end{tabular}

${ }^{1}$ Significance level $(p)$ of pairwise comparisons between high stage of development and the others (Breslow test). ${ }^{2}$ Significance level ( $p$ ) of Breslow test equality of survival distributions for different levels of stage factor.

Table A5. Aggressiveness of Nesidiocoris tenuis cannibalism on different stage class, measured as survival time (hours) ( \pm SE) when caged singly with other conspecifics for $72 \mathrm{~h}$ under laboratory conditions $\left(25 \pm 1^{\circ} \mathrm{C}\right.$ and $\left.60-80 \% \mathrm{RH}\right)$ and without prey.

\begin{tabular}{|c|c|c|c|c|c|c|c|c|c|c|c|c|c|c|c|}
\hline \multirow{3}{*}{ Stage } & \multicolumn{15}{|c|}{ Significance Level ( $p$ ) (Breslow Test) } \\
\hline & \multicolumn{2}{|c|}{ Adult } & \multicolumn{2}{|c|}{$\mathrm{N}-\mathrm{V}$} & \multicolumn{2}{|c|}{ N-IV } & \multicolumn{2}{|c|}{ N-III } & \multicolumn{2}{|c|}{ N-II } & \multicolumn{2}{|c|}{ N-I } & \multirow{2}{*}{$x^{2}$} & \multirow{2}{*}{ df } & \multirow{2}{*}{$p^{2}$} \\
\hline & Value & $p^{1}$ & Value & $p^{1}$ & Value & $p^{1}$ & Value & $p^{1}$ & Value & $p^{1}$ & Value & $p^{1}$ & & & \\
\hline Adult & $72.0 \pm 0.0$ & - & $68.5 \pm 3.5$ & 0.317 & $62.1 \pm 4.5$ & 0.037 & $64.3 \pm 4.2$ & 0.076 & $69.5 \pm 2.5$ & 1.000 & $72.0 \pm 0.0$ & 1.000 & 11.969 & 5 & 0.035 \\
\hline $\mathrm{N}-\mathrm{V}$ & & & $68.7 \pm 3.3$ & - & $62.8 \pm 4.2$ & 0.187 & $62.0 \pm 4.5$ & 0.187 & $69.4 \pm 2.6$ & 0.971 & $69.9 \pm 3.5$ & 0.594 & 3.537 & 4 & 0.472 \\
\hline N-IV & & & & & $64.7 \pm 4.0$ & - & $60.9 \pm 4.4$ & 0.628 & $58.5 \pm 5.4$ & 0.285 & $58.4 \pm 478$ & 0.435 & 1.082 & 3 & 0.781 \\
\hline N-III & & & & & & & $56.6 \pm 5.5$ & - & $63.7 \pm 4.6$ & 0.394 & $54.5 \pm 5.5$ & 0.431 & 2.510 & 2 & 0.285 \\
\hline N-II & & & & & & & & & $59.0 \pm 5.2$ & - & $59.6 \pm 4.9$ & 0.789 & 0.720 & 1 & 0.789 \\
\hline N-I & & & & & & & & & & & $52.8 \pm 6.1$ & - & - & - & - \\
\hline Average & $72.0 \pm 0.0$ & & $68.6 \pm 2.4$ & & $63.2 \pm 2.4$ & & $61.0 \pm 2.3$ & & $64.0 \pm 1.9$ & & $60.7 \pm 1.9$ & & avg. & & \pm 1.0 \\
\hline
\end{tabular}

${ }^{1}$ Significance level $(p)$ of pairwise comparisons between high stage of development and the others (Breslow test). ${ }^{2}$ Significance level ( $p$ ) of Breslow test equality of survival distributions for different levels of stage factor. 
Table A6. Aggressiveness of Nabis pseudoferus predation (intraguild competition) on Nesidiocoris tenuis (both predatory species are in the same or lower stage class), measured as survival time (hours) $( \pm \mathrm{SE})$, when caged one individual of each species during $72 \mathrm{~h}$ under laboratory conditions $\left(25 \pm 1{ }^{\circ} \mathrm{C}\right.$ and $\left.60-80 \% \mathrm{RH}\right)$ and without prey.

\begin{tabular}{|c|c|c|c|c|c|c|c|c|c|c|c|c|c|c|c|}
\hline \multirow{4}{*}{$\begin{array}{c}\text { Species/ } \\
\text { Stage } \\
\text { Nabis } \\
\text { pseudoferus }\end{array}$} & \multicolumn{15}{|c|}{ Significance Level $(p)$ (Breslow Test) } \\
\hline & \multicolumn{15}{|c|}{ Nesidiocoris tenuis } \\
\hline & \multicolumn{2}{|c|}{ Adult } & \multicolumn{2}{|l|}{$\mathrm{N}-\mathrm{V}$} & \multicolumn{2}{|c|}{ N-IV } & \multicolumn{2}{|c|}{ N-III } & \multicolumn{2}{|c|}{ N-II } & \multicolumn{2}{|c|}{ N-I } & \multirow{2}{*}{$\chi^{2}$} & \multirow{2}{*}{ df } & \multirow{2}{*}{$p^{2}$} \\
\hline & Value & $p^{1}$ & Value & $p^{1}$ & Value & $p^{1}$ & Value & $p^{1}$ & Value & $p^{1}$ & Value & $p^{1}$ & & & \\
\hline Adult & $3.5 \pm 1.4$ & - & $9.7 \pm 2.4$ & 0.23 & $10.5 \pm 2.8$ & 0.0020 & $10.2 \pm 2.2$ & 0.0050 & $16.1 \pm 2.2$ & 0.0001 & $16.7 \pm 2.0$ & 0.0001 & 47.912 & 5 & 0.001 \\
\hline $\mathrm{N}-\mathrm{V}$ & & & $29.5 \pm 3.7$ & - & $19.6 \pm 4.5$ & 0.0570 & $16.7 \pm 3.5$ & 0.2190 & $13.4 \pm 2.9$ & 0.0040 & $12.9 \pm 2.2$ & 0.0001 & 12.282 & 4 & 0.015 \\
\hline N-IV & & & & & $16.1 \pm 3.5$ & - & $16.7 \pm 2.7$ & 0.7040 & $17.2 \pm 2.1$ & 0.0580 & $11.8 \pm 2.4$ & 0.9460 & 5.560 & 3 & 0.135 \\
\hline N-III & & & & & & & $21.6 \pm 1.6$ & - & $16.1 \pm 2.1$ & 0.0001 & $19.0 \pm 1.9$ & 0.0001 & 30.993 & 2 & 0.001 \\
\hline N-II & & & & & & & & & $20.1 \pm 1.8$ & - & $19.0 \pm 1.8$ & 0.1440 & 2.137 & 1 & 0.144 \\
\hline N-I & & & & & & & & & & & $20.6 \pm 1.6$ & - & - & - & - \\
\hline Average & $3.5 \pm 1.4$ & & $19.6 \pm 2.7$ & & $15.4 \pm 2.2$ & & $16.3 \pm 1.4$ & & $16.6 \pm 1.0$ & & $16.7 \pm 0.9$ & Tota & avg. & & \pm 0.6 \\
\hline
\end{tabular}

${ }^{1}$ Significance level $(p)$ of pairwise comparisons between high stage of development and the others (Breslow test). ${ }^{2}$ Significance level ( $p$ ) of Breslow test equality of survival distributions for different levels of stage factor.

Table A7. Aggressiveness of Nabis pseudoferus predation (intraguild competition) on Nesidiocoris tenuis (N. pseudoferus was always in a lower stage class than N. tenuis), measured as survival time (hours) $( \pm \mathrm{SE})$, when caged one individual of each species during $72 \mathrm{~h}$ under laboratory conditions $\left(25 \pm 1{ }^{\circ} \mathrm{C}\right.$ and $\left.60-80 \% \mathrm{RH}\right)$ and without prey.

\begin{tabular}{|c|c|c|c|c|c|c|c|c|c|c|c|c|c|c|c|c|c|c|c|}
\hline \multirow{3}{*}{ N.t. } & \multicolumn{19}{|c|}{ Significance Level $(p)$ (Breslow Test) } \\
\hline & \multicolumn{2}{|c|}{ Value } & \multirow{3}{*}{$p^{1}$} & \multicolumn{2}{|c|}{ Value } & \multirow{3}{*}{$p^{1}$} & \multicolumn{2}{|c|}{ Value } & \multirow{3}{*}{$p^{1}$} & \multicolumn{2}{|c|}{ Value } & \multirow{3}{*}{$p^{1}$} & \multicolumn{2}{|c|}{ Value } & \multirow{3}{*}{$p^{1}$} & \multirow{3}{*}{$x^{2}$} & \multirow{3}{*}{ df } & \multirow{3}{*}{$p^{2}$} & \multirow{2}{*}{ N.t. } \\
\hline & N.t. & N.s. & & N.t. & N.s. & & N.t. & N.s. & & N.t. & N.s. & & N.t. & N.s. & & & & & \\
\hline Stage & - & $\mathrm{N}-\mathrm{V}$ & & - & N-IV & & - & N-III & & - & N-II & & - & N-I & & & & & Avg. \\
\hline Adult & $22.6 \pm 1.0$ & $72.0 \pm 0.0$ & 0.001 & $26.1 \pm 2.7$ & $72.0 \pm 0.0$ & 0.001 & $22.4 \pm 3.1$ & $68.5 \pm 3.4$ & 0.001 & $40.5 \pm 5.3$ & $69.6 \pm 2.5$ & 0.001 & $60.2 \pm 4.6$ & $60.2 \pm 5.5$ & 0.910 & 20.372 & 4 & 0.000 & $33.8 \pm 2.2$ \\
\hline $\mathrm{N}-\mathrm{V}$ & & & & $27.1 \pm 3.2$ & $72.0 \pm 0.0$ & 0.001 & $36.9 \pm 3.1$ & $70.7 \pm 1.3$ & 0.001 & $53.2 \pm 4.3$ & $62.2 \pm 4.8$ & 0.670 & $60.9 \pm 4.2$ & $64.8 \pm 4.3$ & 0.300 & 12.446 & 3 & 0.000 & $45.3 \pm 2.3$ \\
\hline N-IV & & & & & & & $27.1 \pm 3.2$ & $72.0 \pm 0.0$ & 0.001 & $33.3 \pm 3.1$ & $69.5 \pm 2.5$ & 0.001 & $39.2 \pm 3.5$ & $62.0 \pm 4.5$ & 0.000 & 2.745 & 2 & 0.250 & $37.0 \pm 2.2$ \\
\hline $\mathrm{N}-\mathrm{III}$ & & & & & & & & & & $23.5 \pm 2.0$ & $72.0 \pm 0.0$ & 0.001 & $24.1 \pm 0.5$ & 72.0 & 0.001 & 1.516 & 1 & 0.210 & $23.8 \pm 1.0$ \\
\hline N-II & & & & & & & & & & & & & $19.4 \pm 1.8$ & 72.0 & 0.001 & - & - & - & $19.4 \pm 1.8$ \\
\hline Avg. & & $72.0 \pm 0.0$ & & & $72.0 \pm 0.0$ & & & $69.6 \pm 1.5$ & & & $68.9 \pm 1.4$ & & & $66.2 \pm 1.7$ & & & & & \\
\hline
\end{tabular}

${ }^{1}$ Significance level $(p)$ of pairwise comparisons between high stage of development and the others (Breslow test). ${ }^{2}$ Significance level (p) of Breslow test equality of survival distributions for different levels of stage factor. N.t. = Nesidiocoris tenuis; N.s. = Nabis pseudoferus. 


\section{References}

1. Coll, M.; Guershon, M. Omnivory in terrestrial arthropods: Mixing plant and prey diets. Annu. Rev. Entomol. 2002, 47, 267-297. [CrossRef] [PubMed]

2. Polis, G.A.; Holt, R.D. Intraguild predation: The dynamics of complex trophic interactions. Trends Ecol. Evol. 1992, 7, 151-154. [CrossRef]

3. Hurd, L.E. Predation: The role of generalist predators in biodiversity and biological control. In Encyclopedia of Entomology; Capinera, J.L., Ed.; Springer: Dordrecht, NL, USA, 2008; pp. 3038-3042.

4. Fox, L.R. Cannibalism in natural populations. Annu. Rev. Ecol. Syst. 1975, 6, 87-106. [CrossRef]

5. Richardson, M.L.; Mitchell, R.F.; Reagel, P.F.; Hanks, L.M. Causes and consequences of cannibalism in noncarnivorous insects. Annu. Rev. Entomol. 2010, 55, 39-53. [CrossRef] [PubMed]

6. Capinera, J.L. Cannibalism. In Encyclopedia of Entomology; Capinera, J.L., Ed.; Springer: Dordrecht, NL, USA, 2008; pp. 710-714.

7. Lawa, Y.H.; Rosenheim, J.A. Presence of conspecific females motivates egg cannibalism owing to lower risk of filial cannibalism. Anim. Behav. 2013, 85, 403-409. [CrossRef]

8. Lida, H. Small within-clutch variance in spiderling body size as a mechanism for avoiding sibling cannibalism in the wolf spider Pardosa pseudoannulata (Aran.: Lycosidae). Popul. Ecol. 2003, 45, 1-6. [CrossRef]

9. Santana, A.F.; Roselino, A.C.; Cappelari, F.A.; Zucoloto, F.S. Cannibalism in insects. In Insect Bioecology and Nutrition for Integrated Pest Management; Panizzi, A.R., Parra, J.R.P., Eds.; CRC Press: Boca Raton, FL, USA, 2012; pp. 177-194.

10. De Vries, T.; Lakes-Harlan, R. Prenatal cannibalism in an insect. Naturwissenschaften 2007, 94, 477-482. [CrossRef]

11. White, T.C.R. Why Does the World Stay Green? Nutrition and Survival of Plant-Eaters; CSIRO Pub.: Sydney, Australia, 2005. [CrossRef]

12. Buskirk, R.E.; Frohlich, C.; Ross, K.G. The natural selection of sexual cannibalism. Am. Nat. 1984, 123, 612-625. [CrossRef]

13. Claessen, D.; de Roos, A.M.; Persson, L. Population dynamic theory of size-dependent cannibalism. Proc. R. Soc. Lond. B 2004, 271, 333-340. [CrossRef]

14. Polis, G.A.; Myers, C.A.; Holt, R.D. The ecology and evolution of intraguild predation: Potential competitors that eat each other. Annu. Rev. Ecol. Syst. 1989, 20, 297-330. [CrossRef]

15. Dick, J.T.A.; Montgomery, I.; Elwood, R.W. Replacement of the indigenous amphipod Gammarus duebeni celticus by the introduced G. pulex: Differential cannibalism and mutual predation. J. Anim. Ecol. 1993, 62, 79-88. [CrossRef]

16. Rosenheim, J.A. Intraguild predation: New theoretical and empirical perspectives. Ecology 2007, 88, 2679-2680. [CrossRef]

17. Brodeur, J.; Boivin, G. Trophic and Guild Interactions in Biological Control; Springer: Dordrecht, The Netherlands, 2006.

18. Snyder, W.E.; Ives, A.R. Generalist predators disrupt biological control by a specialist parasitoid. Ecology 2001, 82, 705-716. [CrossRef]

19. Denno, R.F.; Finkle, D.L.; Langellotto, G.A. Direct and indirect effects of vegetation structure and habitat complexity on predator-prey and predator-predator interactions. In Ecology of Predator-Prey Interaction; Barbosa, P., Castellanos, I., Eds.; Oxford University Press: Oxford, UK, 2005; pp. 211-236.

20. Erbilgin, N.; Dahlsten, D.L.; Chen, P.Y. Intraguild interactions between generalist predators and an introduced parasitoid of Glycaspis brimblecombei (Hom.: Psylloidae). Biol. Control. 2004, 31, 329-337. [CrossRef]

21. Perez-Lachaud, G.; Bachelor, L.; Hardy, I.C.W. Wasp cat wasp: Facultative hyperparasitism and intra-guild predation by bethylid wasps. Biol. Control. 2004, 30, 149-155. [CrossRef]

22. Rosenheim, J.A.; Harmon, J.P. The influence of intraguild predation on the suppression of a shared prey population: An empirical reassessment. In Trophic and Guild Interactions in Biological Control; Brodeur, J., Boivin, G., Eds.; Springer: Dordrecht, The Netherlands, 2006; pp. 1-20.

23. Liman, A.S. Intra- and interspecific interactions between heteropteran generalist predators-The effect of behavioural differences and consequences for biological control. Master's Thesis, Swedish University of Agricultural Sciences, Uppsala, Sweden, 2003. 
24. Cardinale, B.J.; Harvey, C.T.; Gross, K.; Ives, A.R. Biodiversity and biocontrol: Emergent impacts of a multienemy assemblage on pest suppression and crop yield in an agroecosystem. Ecol. Lett. 2003, 6, 857-865. [CrossRef]

25. Cabello, T.; Bonfil, F.; Gallego, J.R.; Fernandez, F.J.; Gamez, M.; Garay, J. Can interactions between an omnivorous hemipteran and an egg parasitoid limit the level of biological control for the tomato pinworm? Environ. Entomol. 2014, 44, 12-26. [CrossRef]

26. Schmidt, J.M.; Taylor, J.R.; Rosenheim, J.A. Cannibalism and intraguild predation. In Predatory Heteroptera: Their Ecology and Use in Biological Control; Coll, M., Ruberson, J.R., Eds.; Entomological Society of America: Lanham, MD, USA, 1998; pp. 131-170.

27. Etzel, L.K.; Legner, E.F. Culture and colonization. In Handbook of Biological Control: Principles and Applications of Biological Control; Bellows, T.S., Fisher, T.W., Caltagirone, D.L., Dahlsten, D.L., Gordh, G., Huffaker, C.B., Eds.; Academic Press: San Diego, CA, USA, 1999; pp. 125-197.

28. Ito, K. A simple mass-rearing method for predaceous Orius bugs in the laboratory. Appl. Entomol. Zool. 2007, 42, 573-577. [CrossRef]

29. Hodek, I.; Evans, E.W. Food relationships. In Ecology and Behaviour of the Ladybird Beetles (Coccinellidae); Hodek, I., van Emden, H.F., Honek, A., Eds.; John Wiley \& Sons, Ltd.: Chichester, UK, 2012; pp. 141-274.

30. de Clercq, P.; Coudron, T.A.; Riddick, E.W. Production of heteropteran predators. In Mass Production of Beneficial Organisms: Invertebrates and Entomopathogens; Morales-Ramos, J.A., Rojas, G., Shapiro-Ilan, D.I., Eds.; Academic Press: Amsterdam, NL, USA, 2014; pp. 57-100.

31. Riddick, E.W.; Chen, H. Production of coleopteran predators. In Mass Production of Beneficial Organisms: Invertebrates and Entomopathogens; Morales-Ramos, J.A., Rojas, G., Shapiro-Ilan, D.I., Eds.; Academic Press: Amsterdam, NL, USA, 2014; pp. 17-56.

32. Vila, E.; Cabello, T. Biosystems engineering applied to greenhouse pest control. In Biosystems Engineering: Biofactories for Food Production in the XXI Century; Torres, I., Guevara, R., Eds.; Springer: Berlin, Germany, 2014; pp. 99-128.

33. Mills, N.J. Voracity, cannibalism and coccinellid predation. Ann. Appl. Biol. 1982, 101, 144-148. [CrossRef]

34. Chang, G.C.; Kareiva, P. The case for indigenous generalists in biological control. In Theoretical Approaches to Biological Control; Hawkins, B.A., Cornell, H.V., Eds.; Cambridge University Press: Cambridge, UK, 2004; pp. 103-115.

35. Pires, E.M.; Zanuncio, J.C.; Serrao, J.C. Cannibalism of Brontocoris tabidus and Podisus nigrispinus during periods of pre-release without food or fed with Eucalyptus cloeziana plants. Phytoparasitica 2011, 39, $27-34$. [CrossRef]

36. Moerkens, R.; Berckmoes, E.; van Damme, V.; van den Broecke, S.; Wittemans, L.; Casteels, H.; Tirry, L.; de Clercq, P.; de Vis, R. Optimization of pest control by the predatory bug Macrolophus pygmaeus in greenhouse tomato production. IOBC WPRS Bull. 2014, 102, 157-162.

37. Rudolf, V.H.W. The interaction of cannibalism and omnivory: Consequences for community dynamics. Ecology 2007, 88, 2697-2705. [CrossRef] [PubMed]

38. Persson, L. Dynamics of Age- and Stage-Structured Populations and Communities. In Oxford Bibliographies in Ecology; 2014; Available online: https://www.oxfordbibliographies.com/view/document/obo-9780199830060/ obo-9780199830060-0036.xml?rskey=Oo4p3m\&result=1\&q=Dynamics +of +age-+and+stage-structured + populations+and+communities\#firstMatch (accessed on 11 February 2020).

39. Cabello, T.; Gallego, J.R.; Fernandez, F.J.; Gamez, M.; Vila, E.; del Pino, M.; Hernandez-Suarez, E. Biological control strategies for the South American tomato moth (Lep.: Gelechiidae) in greenhouse tomatoes. J. Econ. Entomol. 2012, 105, 2085-2096. [CrossRef] [PubMed]

40. Vandermeer, J.H. The ecology of Agroecosystems; Jones and Bartlett Publishers: Sudbury, UK, 2011.

41. Sanchez, J.A. Zoophytophagy in the plantbug Nesidiocoris tenuis. Agric. For. Entomol. 2008, 10, 75-80. [CrossRef]

42. Wheeler, A.G.; Henry, T.J. A synthesis of the holarctic Miridae (Het.): Distribution, Biology, and Origin, with Emphasis on North. America; Entomological Society of America: Lanham, MD, USA, 1992.

43. Rabitsch, W. Alien true bugs of Europe (Insecta: Hem.: Het.). Zootax. 2008, 1827, 1-44. [CrossRef]

44. Wheeler, A.G. Predacious plant bugs (Miridae). In Heteroptera of Economic Importance; Schaefer, C.W., Panizzi, A.R., Eds.; CRC Press: Boca Raton, FL, USA, 2000; pp. 657-693. 
45. Sanchez, J.A.; Lacasa, A. Impact of the zoophtophagous plant bug Nesidiocoris tenuis (Het.: Miridae) on tomato yield. J. Econ. Entomol. 2008, 101, 1864-1870. [CrossRef]

46. Wheeler, A.G. Biology of the Plant Bugs (Hem.: Miridae): Pests, Predators, Opportunists; Cornell University Press: Ithaca, NY, USA, 2001.

47. Valderrama, K.; Granobles, J.; Valencia, E.; Sanchez, M. Nesidiocoris tenuis (Hem.: Miridae) predator in tobacco crops (Nicotiana tabacum). Rev. Colomb. Entomol. 2007, 33, 141-145. [CrossRef]

48. Li, L.R.; Xue, R.F.; Wang, X.J.; Zeng, F.R. Predation of Nesidiocoris tenuis to Trialeurodes vaporariorum and Plutella xylostella. J. Agr. Univ. Hebei 2008, 31, 84-87.

49. Perez-Hedo, M.; Urbaneja, A. Prospects for predatory mirid bugs as biocontrol agents of aphids in sweet peppers. J. Pest. Sc. 2015, 88, 65-73. [CrossRef]

50. Fagan, W.F. Omnivory as a stabilizing feature of natural communities. Am. Nat. 1997, 150, 554-567. [CrossRef]

51. Pericart, J. Hemipteres Nabidae d'Europe Occidentale et du Maghreb; Federation Française des Societes de Sciences Naturelles: Paris, France, 1987.

52. Lattin, J.D. Bionomics of the Nabidae. Annu. Rev. Entomol. 1989, 34, 383-400. [CrossRef]

53. Braman, S.K. Damsel bugs (Nabidae). In Heteroptera of Economic Importance; Schaefer, C.W., Panizzi, A.R., Eds.; CRC Press: Boca Raton, FL, USA, 2000; pp. 639-656.

54. Hagen, K.S.; Mills, N.J.; Gordh, T.G.; McMurtry, J.A. Terrestrial arthropod predators of insect and mite pests. In Handbook of Biological Control: Principles and Applications of Biological Control; Bellows, T.S., Fisher, T.W., Caltagirone, D.L., Dahlsten, D.L., Gordh, G., Huffaker, C.B., Eds.; Academic Press: San Diego, CA, USA, 1999; pp. 383-503.

55. Obrtel, R. Variation in abundance and dominance of insects inhabiting lucerne fields. Acta Entomol. Bohemos. 1970, 67, 175-187.

56. Puchkov, A.V. Particulars of the biology of predacious Nabis spp. Zash. Rast. 1980, 8, 1-44.

57. Cabello, T. Natural enemies of noctuid pests in alfalfa, corn, cotton and soybean crops in Southern Spain. J. Appl. Entomol. 1988, 108, 80-88. [CrossRef]

58. Cabello, T. Control biológico de noctuidos y otros lepidópteros. In Control Biológico de Plagas; Jacas, J., Urbaneja, A., Eds.; Phytoma España: Valencia, Spain, 2009; pp. 279-306.

59. Aydemir, M.; Toros, S. Natural enemies of Tetranychus urticae (Acari: Tetranychidae) on bean plants in Erzincan. In Proceedings of the Second Turkish National Congress of Biological Control, Ankara, Turkey, 12-14 February 1990; pp. 261-271.

60. Ulusoy, M.R.; Ulgenturk, S. The natural enemies of whiteflies (Hem.: Aleyrodidae) in southern Anatolia. Zool. Middle East. 2003, 28, 119-124. [CrossRef]

61. Walzer, A.; Shausbergerb, P. Cannibalism and interspecific predation in the phytoseiid mites Phytoseiulus persimilis and Neoseiulus californicus: Predation rates and effects on reproduction and juvenile development. BioControl 1999, 43, 457-468. [CrossRef]

62. Schausberger, P.; Croft, B.A. Cannibalism and intraguild predation among phytoseiid mites: Are aggressiveness and prey preference related to diet specialization? Exp. Appl. Acarol. 2000, 24, 709-725. [CrossRef]

63. Joarder, A.H. Hypergeometric distribution and its application in statistics. In International Encyclopedia of Statistical Science; Lovric, M., Ed.; Springer: Berlin, Germany, 2011; pp. 1-7. [CrossRef]

64. Altmann, J. Observational sampling methods for insect behavioral ecology. Fla. Entomol. 1984, 67, 50-56. [CrossRef]

65. Martin, P.; Bateson, P. Measuring Behavior: An. Introductory Guide; Cambridge University Press: Cambridge, UK, 2004.

66. Kaplan, E.L.; Meier, P. Nonparametric estimations from incomplete observation. J. Am. Stat. Assoc. 1958, 53, 457-481. [CrossRef]

67. Borgan, O. Kaplan-Meier Estimator. In Encyclopedia of Biostatistics; Armitage, P., Colton, T., Eds.; Willey Online Library, 2005; Available online: https://onlinelibrary.wiley.com/doi/abs/10.1002/0470011815.b2a11042 (accessed on 11 February 2020). [CrossRef]

68. Breslow, N.E. Analysis of survival data under the proportional hazards model. Int. Stat. Rev. 1975, 43, 45-58. [CrossRef]

69. IBM. IBM SPSS Advanced Statistics 25; IBM Corp.: Armonk, NY, USA, 2017. 
70. STATGRAPHICS Centurion User Manual; Statgraphics Technologies Incorporated: The Plains, VA, USA, 2009.

71. Braman, S.K.; Yeargan, K.V. Intraplant distribution of three Nabis species (Hem.: Nabidae), and impact of N. roseipennis on green cloverworm populations in soybean. Environ. Entomol. 1989, 18, 240-244. [CrossRef]

72. Wilson, L.T.; Gutierrez, A.P. Within-plant distribution of predators on cotton: Comments on sampling and predator efficiencies. Hilgardia 1980, 48, 3-11. [CrossRef]

73. Wineriter, S.A.; Walker, T.J. Insect marking techniques: Durability of materials. Ent. News 1984, 95, 117-123.

74. Carreño, R.; Andujar, A.; Cabello, T. Evaluacion de la eficacia de pesticidas agricolas. In Actas de la $V$ Conferencia Española de Biometria; Anonymous, Ed.; Sociedad Española de Biometria: Valencia, Spain, 1995; pp. 139-142. [CrossRef]

75. Perkins, P.V.; Watson, T.F. Biology of Nabis alternatus (Hem.: Nabidae). Ann. Entomol. Soc. Am. 1972, 65, 54-57. [CrossRef]

76. Takizawa, T.; Snyder, W.E. Predator biodiversity increases the survival of juvenile predators. Oecologia 2011, 166, 723-730. [CrossRef] [PubMed]

77. Koschel, H. Zur kenntnis der raubwanze Himacerus apterus F. (Het.: Nabidae). J. Appl. Entomol. 1971, 68, 113-137. [CrossRef]

78. Wagner, J.D.; Wise, D.H. Cannibalism regulates densities of young wolf spiders: Evidence from field and laboratory experiments. Ecology 1996, 77, 639-652. [CrossRef]

79. Wise, D.H. Cannibalism, food limitation, intraspecific competition, and the regulation of spider populations. Annu. Rev. Entomol. 2006, 51, 441-465. [CrossRef]

80. Edgar, W.D. Prey and predators of the wolf spider Lycosa lugubris. Entomol. Mon. Mag. 1970, 106, 71-73. [CrossRef]

81. Buddle, C.M.; Walker, S.E.; Rypstra, A.L. Cannibalism and density-dependent mortality in the wolf spider Pardosa milvina (Aran.: Lycosidae). Can. J. Zool. 2003, 81, 1293-1297. [CrossRef]

82. Joyner, K.; Gould, F. Conspecific tissues and secretions as sources of nutrition. In Nutritional Ecology of Insects, Mites, Spiders, and Related Invertebrates; Slansky, F., Rodriguez, J.G., Eds.; Wiley: New York, NY, USA, 1987; pp. 697-719.

83. Mayntz, D.; Toft, S. Nutritional value of cannibalism and the role of starvation and nutrient imbalance for cannibalistic tendencies in a generalist predator. J. Anim. Ecol. 2006, 75, 288-297. [CrossRef] [PubMed]

84. Agarwala, B.K.; Dixon, A.F.G. Laboratory study of cannibalism and interspecific predation in ladybirds. Ecol. Entomol. 1992, 17, 303-309. [CrossRef]

85. Michaud, J.P. A comparative study of larval cannibalism in three species of ladybird. Ecol. Entom. 2003, 28, 92-101. [CrossRef]

86. Polis, G.A. Exploitation competition and the evolution of interference, cannibalism, and intraguild predation in age/size-structured populations. In Size-Structured Populations: Ecology and Evolution; Ebenman, B., Persson, L., Eds.; Springer-Verlag: Berlin, Germany, 1988; pp. 185-202.

87. Claessen, D.; de Roos, A.M.; Persson, L. Dwarfs and giants: Cannibalism and competition in size-structured populations. Am. Nat. 2000, 155, 219-237. [CrossRef]

88. Laycock, A.; Camm, E.; van Laerhoven, S.; Gillespie, D. Cannibalism in a zoophytophagous omnivore is mediated by prey availability and plant substrate. Insect Beha. 2006, 19, 219-229. [CrossRef]

89. Moreno-Ripoll, R.; Agustin, N.; Berruezo, R.; Gabarra, R. Conspecific and heterospecific interactions between two omnivorous predators on tomato. Biol. Control. 2012, 62, 189-196. [CrossRef]

90. Hamdi, F.; Chadoeuf, J.; Chermiti, B.; Bonato, O. Evidence of cannibalism in Macrolophus pygmaeus, a natural enemy of whiteflies. J. Insect Behav. 2013, 26, 614-621. [CrossRef]

91. Urbaneja, A.; Tabia, G.; Stansly, P. Influence of host plant and prey availability on developmental time and survival of Nesidiocoris tenuis (Het.: Miridae). Biocontrol Sci. Techn. 2005, 15, 513-518. [CrossRef]

92. Puysseleyr, V.; de Man, S.; Hofte, M.; de Clercq, P. Plantless rearing of the zoophytophagous bug Nesidiocoris tenuis. Biocontrol 2013, 58, 205-213. [CrossRef]

93. Nakaishi, K.; Fukui, Y.; Arakawa, R. Reproduction of Nesidiocoris tenuis on sesame. J. Appl. Entomol. Zool. 2011, 55, 199-205. [CrossRef]

94. Polis, G.A. Intraspecific predation and "infant killing" among invertebrates. In Infanticide: Comparative and Evolutionary Perspectives; Hausfater, G., Hrdy, S.B., Eds.; Alsinde: New York, NY, USA, 1984; pp. 87-104.

95. Leon-Beck, M.; Coll, M. Plant and prey consumption cause a similar reductions in cannibalism by an omnivorous bug. J. Insect Behav. 2007, 20, 67-77. [CrossRef] 
96. Bernays, E.A. Evolution of feeding behavior in insect herbivores. Bioscience 1998, 48, 35-44. [CrossRef]

97. Snyder, W.E.; Snyde, G.B.; Finke, D.L.; Straub, C.S. Predator biodiversity strengthens herbivore suppression. Ecol. Lett. 2006, 9, 789-796. [CrossRef]

98. Rosenheim, J.A.; Kaya, H.K.; Ehler, L.E.; Marois, J.J.; Jaffee, B.A. Intraguild predation among biological-control agents: Theory and evidence. Biol. Control. 1995, 5, 303-335. [CrossRef]

99. Mochizuki, A.; Naka, H.; Hamasaki, K.; Mitsunaga, T. Larval cannibalism and intraguild predation between the introduced green lacewing, Chrysoperla carnea, and the indigenous trash carrying green lacewing, Mallada desjardinsi (Neur.: Chrysopidae), as a case study of potential nontarget effect assessment. Environ. Entomol. 2006, 35, 1298-1303. [CrossRef]

100. Cohen, A.C. How carnivorous bugs feed. In Heteroptera of Economic Importance; Schaefer, C.W., Panizzi, A.R., Eds.; CRC Press: Boca Raton, FL, USA, 2000; pp. 563-570.

101. Torres, J.B.; Boyd, D.W. Zoophytophagy in predatory Hemiptera. Braz. Arch. Biol. Technol. 2009, 52, 1199-1208. [CrossRef]

102. Schuh, R.T.; Slater, J.A. True Bugs of the World (Hem.: Heteroptera): Classification and Natural History; Cornell University Press: Ithaca, NY, USA, 1995.

103. Fernandez, F.J.; Gallego, J.R.; Valencia, A.; Gamez, M.; Varga, Z.; Garay, J.; Cabello, T. Cannibalism: Do risks of fighting and reprisal reduce predatory rates? Community Ecol. 2017, 18, 87-96. [CrossRef]

104. Pumarino, L.; Alomar, O.; Lundgren, J.G. The influence of intraguild competitors on reproductive decisions by two predatory Heteroptera, Orius insidiosus (Anthocoridae) and Nabis americoferus (Nabidae). Biocontrol Sci. Techn. 2011, 21, 1321-1330. [CrossRef]

105. Polis, G.A. Age structure component of niche width and intraspecific resource partitioning: Can age groups function as ecological species? Am. Nat. 1984, 123, 541-564. [CrossRef]

106. May, R.M. Prologue. In Size-Structured Populations: Ecology and Evolution; Ebenman, B., Persson, L., Eds.; Springer-Verlag: Berlin, Germany, 1988; pp. 1-2.

107. Miller, T.E.X.; Rudolf, V.H.W. Thinking inside the box: Community-level consequences of stage-structured populations. Trends Ecol. Evolut. 2011, 26, 457-466. [CrossRef]

108. Rudolf, V.H.W. Seasonal shifts in predator body size diversity and trophic interactions in size-structured predator-prey systems. J. Anim. Ecol. 2012, 81, 524-532. [CrossRef] [PubMed]

(C) 2020 by the authors. Licensee MDPI, Basel, Switzerland. This article is an open access article distributed under the terms and conditions of the Creative Commons Attribution (CC BY) license (http://creativecommons.org/licenses/by/4.0/). 